\title{
Quality Evaluation of Ayurvedic Crude Drug Daruharidra, Its Allied Species, and Commercial Samples from Herbal Drug Markets of India
}

\author{
Sharad Srivastava and A. K. S. Rawat \\ Pharmacognosy and Ethnopharmacology Division, National Botanical Research Institute, Lucknow 226002, India \\ Correspondence should be addressed to A. K. S. Rawat; pharmacognosy1@rediffmail.com
}

Received 27 April 2012; Revised 12 December 2012; Accepted 12 December 2012

Academic Editor: Annie Shirwaikar

Copyright (C) 2013 S. Srivastava and A. K. S. Rawat. This is an open access article distributed under the Creative Commons Attribution License, which permits unrestricted use, distribution, and reproduction in any medium, provided the original work is properly cited.

\begin{abstract}
Berberis aristata known as "Daruharidra" in Ayurveda is a versatile medicinal plant used singly or in combination with other medicinal plants for treating a variety of ailments like jaundice, enlargement of spleen, leprosy, rheumatism, fever, morning/evening sickness, snakebite, and so forth. A major bioactive marker of this genus is an alkaloid berberine, which is known for its activity against cholera, acute diarrhea, amoebiasis, and latent malaria and for the treatment of oriental sore caused by Leishmania tropica. Although the roots of $B$. aristata are considered as the official drug (Ayurvedic Pharmacopoeia of India), the study revealed that different species of Berberis, namely. B. asiatica, B. chitria, and B. lycium are also used under the name of Daruharidra in different parts of the country. Detailed physicochemical and phytochemical studies of subjects like total ash, acid insoluble ash, tannins, and total alkaloids were calculated from the shade dried powdered material according to the recommended procedures. Further, heavy metal studies and quantitative estimation of berberine through HPTLC have also been performed as per ICH guidelines. A detailed study of four Berberis species, namely B. aristata, B. asiatica, B. chitria, and B. lycium, which are implicated as Daruharidra and collected from wild and ten commercial samples procured from various important drug markets in India has been carried out, which may be useful to pharmaceutical industries for the authentication of the commercial samples and exploring the possibilities of using other species as a substitute of $B$. aristata.
\end{abstract}

\section{Introduction}

Berberis aristata known as "Daruharidra" in Ayurveda is a versatile medicinal plant used singly or in combination with other medicinal plants for treating a variety of ailments like jaundice, enlargement of spleen, leprosy, rheumatism, fever, morning/evening sickness, and snakebite, and so forth [1-4]. In addition, the decoction of root or stem of Berberis known as "Rasaut" is specifically used in eye disease, skin disorders, and indolent ulcers. Its use in the management of infected wounds has also been described in Ayurvedic classical texts [5]. The major alkaloid of the plant is berberine, which is known for its activity against cholera [6], acute diarrhea
[7], amoebiasis, and latent malaria and for the treatment of oriental sore caused by Leishmania tropica [4].

Although the roots of $B$. aristata are considered as the official drug [8], the study revealed that different species of Berberis, namely, B. asiatica, B. chitria and B. lycium are also used as Daruharidra in different parts of the country. In southern India, however, Coscinium fenestratum is used as "Daruharidra." The study also shown that most of the market material sold as Daruharidra consists of mostly the stem parts than the roots of Berberis species.

As such there are different alkaloids available to differentiate different Berberis species. Several workers have also done molecular analysis of different Berberis species including the 
TABLE 1: Comparative botanical analysis of the roots of four Berberis species.

\begin{tabular}{|c|c|c|c|c|}
\hline Characters & Berberis aristata & Berberis asiatica & Berberis chitria & Berberis lycium \\
\hline Macroscopic & $\begin{array}{l}\text { Outer surface of the } \\
\text { bark, creamish brown, } \\
\text { and the inner surface } \\
\text { attached to wood is } \\
\text { yellowish brown. Bark } \\
2 \mathrm{~mm} \text { thick, knotty and } \\
\text { brittle. } \\
\text { Cut surface of the wood } \\
\text { is bright yellow. } \\
\text { Fracture hard, odourless } \\
\text { and bitter in taste. } \\
\text { Fine longitudinal ridges } \\
\text { and flakes are present }\end{array}$ & $\begin{array}{l}\text { Outer surface creamish } \\
\text { brown but inner surface } \\
\text { is muddy yellow. } \\
\text { Bark } 2 \text { mm thick, friable } \\
\text { separated out } \\
\text { immediately from } \\
\text { woody part. } \\
\text { Cut surface of the wood } \\
\text { lemon yellow. } \\
\text { Fracture very hard, } \\
\text { odour phenolic and very } \\
\text { bitter in taste }\end{array}$ & $\begin{array}{l}\text { Outer surface light } \\
\text { brown, grooved with } \\
\text { transverse marks, bark } \\
\text { not easily detachable. } \\
\text { Bark upto } 5 \text { mm thick, } \\
\text { split longitudinally. } \\
\text { Cut surface bright } \\
\text { yellow. } \\
\text { Fracture hard, odour } \\
\text { faintly phenolic and very } \\
\text { bitter in taste }\end{array}$ & $\begin{array}{l}\text { Outer surface grayish } \\
\text { brown with shinnings. } \\
\text { Bark up to } 3 \mathrm{~mm} \text { thick, } \\
\text { brittle, warty and easily } \\
\text { detachable. } \\
\text { Cut surface deep yellow. } \\
\text { Fracture hard, odour } \\
\text { phenolic and bitter in } \\
\text { taste }\end{array}$ \\
\hline Cork cells & Brown, 10-20 layered & Brown, 12-15 layered & $\begin{array}{l}\text { Dark brown, } 8-10 \\
\text { layered }\end{array}$ & $\begin{array}{l}\text { Dark brown, } 8-11 \\
\text { layered }\end{array}$ \\
\hline $\begin{array}{l}\text { Cork } \\
\text { Cambium }\end{array}$ & 2 or 3 layered & 1 or 2 layered & 1 or 2 layered & 2 or 3 layered \\
\hline Cortical zone & $\begin{array}{l}\text { 30-35 layered, outer } 4 \text { to } \\
6 \text { layers compressed, } \\
\text { devoid of stone cells }\end{array}$ & 18-20 layered & 12-20 layered & 17-22 layered \\
\hline Sclereids & $\begin{array}{l}\text { Solitary or in group of } 2 \\
\text { to } 10\end{array}$ & $\begin{array}{l}\text { Rarely solitary but in } \\
\text { group of } 2 \text { to } 12 \text {, } \\
\text { comparatively more than } \\
\text { other three species }\end{array}$ & 2 to 4 in groups & 2 to 4 in groups \\
\hline $\begin{array}{l}\text { Pericyclic } \\
\text { fibres }\end{array}$ & $\begin{array}{l}\text { Mostly solitary but } \\
\text { sometimes in groups of } 2 \\
\text { to } 10\end{array}$ & $\begin{array}{l}\text { Interrupted with stone } \\
\text { cells }\end{array}$ & $\begin{array}{l}\text { Frequently present } \\
\text { comparatively lesser } \\
\text { than } B \text {. aristata and } B . \\
\text { asiatica }\end{array}$ & $\begin{array}{l}\text { Frequently present } \\
\text { comparatively lesser } \\
\text { than other three species }\end{array}$ \\
\hline Vessels & $\begin{array}{l}\text { Solitary or in group of } 2 \\
\text { or } 3\end{array}$ & $\begin{array}{l}\text { Solitary or in group of } 2 \\
\text { or } 5\end{array}$ & $\begin{array}{l}\text { Solitary or in group of } 2 \\
\text { or } 3\end{array}$ & $\begin{array}{l}\text { Solitary or in group of } 3 \\
\text { or } 4\end{array}$ \\
\hline $\begin{array}{l}\text { Medullary } \\
\text { Rays }\end{array}$ & 2 to 4 cells broad & 2 to 3 cells broad & 2 to 4 cells broad & 2 to 5 cells broad \\
\hline
\end{tabular}

TABLE 2: Comparative Maceration study of the roots of four Berberis species.

\begin{tabular}{|c|c|c|c|c|c|c|c|c|}
\hline \multirow{2}{*}{$\begin{array}{l}\text { Macerated elements } \\
\text { (in } \mu \mathrm{m})\end{array}$} & \multicolumn{2}{|c|}{ Berberis aristata } & \multicolumn{2}{|c|}{ Berberis asiatica } & \multicolumn{2}{|c|}{ Berberis chitria } & \multicolumn{2}{|c|}{ Berberis lycium } \\
\hline & Mean & $\mathrm{SD}$ & Mean & SD & Mean & SD & Mean & SD \\
\hline \multicolumn{9}{|l|}{ Tracheids } \\
\hline Length & 491.024 & \pm 125.571 & 658.613 & \pm 253.672 & 348.308 & \pm 129.626 & 282.836 & \pm 4.598 \\
\hline Width & 13.062 & \pm 4.600 & 13.749 & \pm 6.481 & 12.221 & \pm 2.645 & 12.603 & \pm 0.231 \\
\hline \multicolumn{9}{|l|}{ Vessels } \\
\hline Length & 259.720 & \pm 158.670 & 494.964 & \pm 181.477 & 160.405 & \pm 187.958 & 140.108 & \pm 14.862 \\
\hline Width & 25.590 & \pm 18.198 & 20.623 & \pm 16.203 & 19.859 & \pm 11.533 & 24.629 & \pm 0.468 \\
\hline \multicolumn{9}{|l|}{ Fibres } \\
\hline Length & 645.481 & \pm 259.182 & 522.462 & \pm 246.290 & 476.632 & \pm 337.029 & 517.879 & \pm 2.217 \\
\hline Width & 14.666 & \pm 3.986 & 11.457 & \pm 3.240 & 10.693 & \pm 2.645 & 10.884 & \pm 0.258 \\
\hline \multicolumn{9}{|l|}{ Tracheidal fibres } \\
\hline Length & 694.064 & \pm 324.992 & 714.949 & \pm 181.477 & 760.778 & \pm 194.440 & 368.931 & \pm 15.691 \\
\hline Width & 12.986 & \pm 2.916 & 11.457 & \pm 3.240 & 11.457 & \pm 3.240 & 12.218 & \pm 0.250 \\
\hline
\end{tabular}


TABLE 3: Comparative botanical analysis of the stems of four Berberis species.

\begin{tabular}{|c|c|c|c|c|}
\hline Characters & Berberis aristata & Berberis asiatica & Berberis chitria & Berberis lycium \\
\hline Macroscopic & $\begin{array}{l}\text { Outer surface of bark, } \\
\text { creamish brown, inner } \\
\text { surface yellowish brown, } \\
\text { knotty, thin, and brittle. } \\
\text { Cut surface light yellow. } \\
\text { Fracture hard and bitter } \\
\text { in taste }\end{array}$ & $\begin{array}{l}\text { Outer surface of bark } \\
\text { grayish brown and } \\
\text { friable, fine longitudinal } \\
\text { ridges and small warts, } \\
\text { inner surface dark } \\
\text { brown. } \\
\text { Fine longitudinal ridges } \\
\text { and small warts below } \\
\text { the bark surface leaving } \\
\text { dark brown. } \\
\text { Cut surface yellowish } \\
\text { cream. } \\
\text { Fracture very hard and } \\
\text { very bitter in taste }\end{array}$ & $\begin{array}{l}\text { Outer surface light } \\
\text { brown, split } \\
\text { longitudinally, warts } \\
\text { comparatively large in } \\
\text { size. Whole bark pealed } \\
\text { off leaving coffee brown } \\
\text { almost smooth inner } \\
\text { surface. } \\
\text { Cut surface light yellow. } \\
\text { Fracture hard and bitter } \\
\text { in taste }\end{array}$ & $\begin{array}{l}\text { Outer surface grayish } \\
\text { brown with shining. } \\
\text { Bark easily detachable, } \\
\text { thin, brittle, and twisted } \\
\text { Cut surface canary } \\
\text { yellow. } \\
\text { Fracture hard and bitter } \\
\text { in taste }\end{array}$ \\
\hline Cork cells & Brown, 15-25 layered & Brown, 08-10 layered & $\begin{array}{l}\text { Dark brown, } 8-15 \\
\text { layered }\end{array}$ & $\begin{array}{l}\text { Dark brown, 7-19 } \\
\text { layered }\end{array}$ \\
\hline $\begin{array}{l}\text { Cork } \\
\text { Cambium }\end{array}$ & 2 or 3 layered & 1 or 2 layered & 1 or 2 layered & 2 or 3 layered \\
\hline Cortical zone & $\begin{array}{l}20-25 \text { layered, outer } 4 \text { to } \\
6 \text { layers compressed, } \\
\text { devoid of stone cells }\end{array}$ & 16-18 layered & 20-24 layered & 20-26 layered \\
\hline Sclereids & $\begin{array}{l}\text { Solitary or in group of } 2 \\
\text { to } 10\end{array}$ & $\begin{array}{l}\text { Sometimes solitary but } \\
\text { in group of } 2 \text { to } 4 \text {, } \\
\text { comparatively more than } \\
\text { other three species }\end{array}$ & Solitary & $\begin{array}{l}\text { Scattered or sometimes } \\
\text { in linear groups }\end{array}$ \\
\hline $\begin{array}{l}\text { Pericyclic } \\
\text { fibres }\end{array}$ & $\begin{array}{l}\text { Mostly solitary but } \\
\text { sometimes in groups of } 2 \\
\text { to } 10\end{array}$ & $\begin{array}{l}\text { Interrupted with stone } \\
\text { cells }\end{array}$ & $\begin{array}{l}\text { Frequently present } \\
\text { comparatively lesser } \\
\text { than } B \text {. aristata and } B \text {. } \\
\text { asiatica }\end{array}$ & $\begin{array}{l}\text { Frequently present } \\
\text { comparatively lesser } \\
\text { than other three species }\end{array}$ \\
\hline Vessels & $\begin{array}{l}\text { In group of } 2 \text { to } 3 \text { or } \\
\text { solitary }\end{array}$ & $\begin{array}{l}\text { Solitary or in group of } 2 \\
\text { to } 4\end{array}$ & $\begin{array}{l}\text { Mostly in group of } 2 \text { to } 3 \\
\text { or solitary }\end{array}$ & $\begin{array}{l}\text { Solitary or in group of } 3 \\
\text { or } 4\end{array}$ \\
\hline $\begin{array}{l}\text { Medullary } \\
\text { Rays }\end{array}$ & 2 to 4 cells broad & 2 to 5 cells broad & 2 to 4 cells broad & 1 to 3 cells broad \\
\hline Pith & Present & Present & Present & Present \\
\hline
\end{tabular}

TABLE 4: Comparative Maceration study of the stems of four Berberis species.

\begin{tabular}{|c|c|c|c|c|c|c|c|c|}
\hline \multirow{2}{*}{ Macerated elements } & \multicolumn{2}{|c|}{ Berberis aristata } & \multicolumn{2}{|c|}{ Berberis asiatica } & \multicolumn{2}{|c|}{ Berberis chitria } & \multicolumn{2}{|c|}{ Berberis lycium } \\
\hline & Mean & Seed, & Mean & Seed, & Mean & SD & Mean & $\mathrm{SD}$ \\
\hline \multicolumn{9}{|l|}{ Trachieds } \\
\hline Length & 439.03 & \pm 75.641 & 625.583 & \pm 169.764 & 360.398 & \pm 102.082 & 262.436 & \pm 3.145 \\
\hline Width & 12.85 & \pm 4.600 & 12.417 & \pm 6.481 & 12.420 & \pm 2.645 & 11.603 & \pm 0.384 \\
\hline \multicolumn{9}{|l|}{ Vessels } \\
\hline Length & 459.72 & \pm 48.896 & 594.694 & \pm 102.728 & 468.908 & \pm 082.487 & 440.168 & \pm 14.862 \\
\hline Width & 20.69 & \pm 10.186 & 18.623 & \pm 16.203 & 19.859 & \pm 11.503 & 20.629 & \pm 0.860 \\
\hline \multicolumn{9}{|l|}{ Fibres } \\
\hline Length & 627.38 & \pm 158.092 & 543.216 & \pm 180.780 & 424.426 & \pm 292.948 & 497.796 & \pm 2.217 \\
\hline Width & 13.41 & \pm 3.986 & 11.246 & \pm 3.240 & 10.993 & \pm 2.645 & 18.443 & \pm 0.258 \\
\hline \multicolumn{9}{|l|}{ Tracheidal fibres } \\
\hline Length & 625.08 & \pm 224.887 & 706.843 & \pm 086.878 & 670.678 & \pm 094.087 & 334.632 & \pm 15.691 \\
\hline Width & 11.49 & \pm 2.916 & 11.247 & \pm 3.240 & 11.457 & \pm 3.240 & 12.268 & \pm 0.250 \\
\hline
\end{tabular}




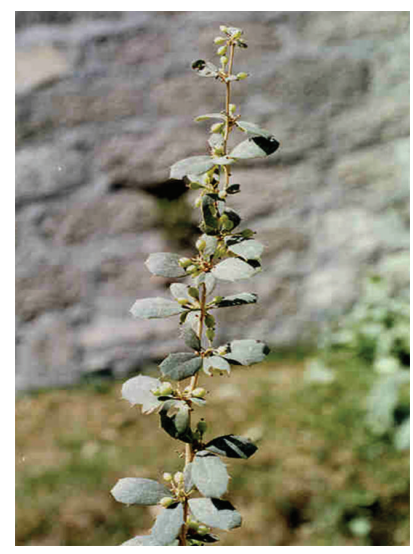

A flowering twig

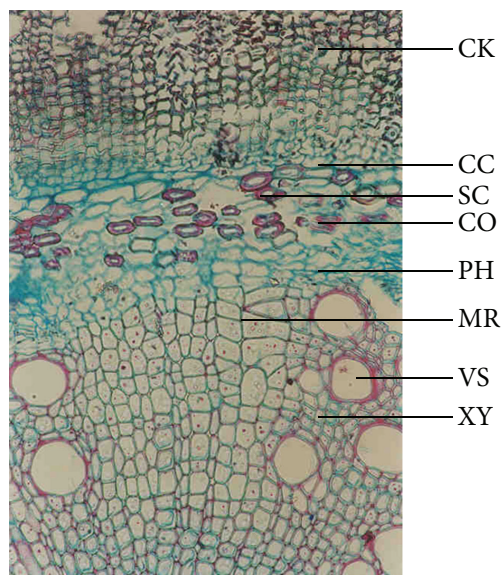

T.S. of root

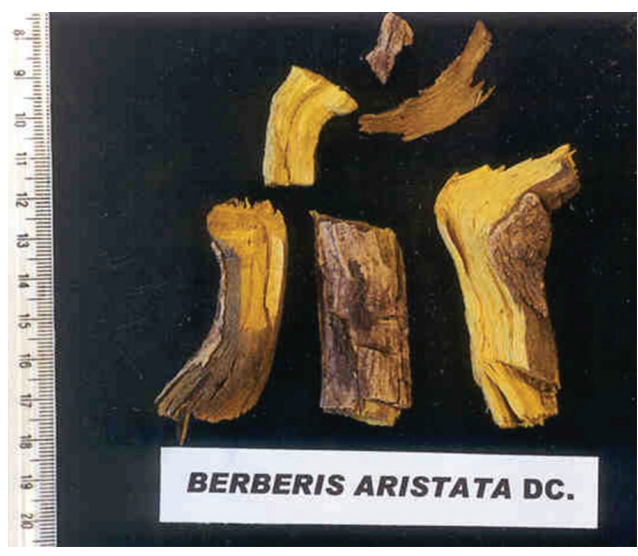

Root+

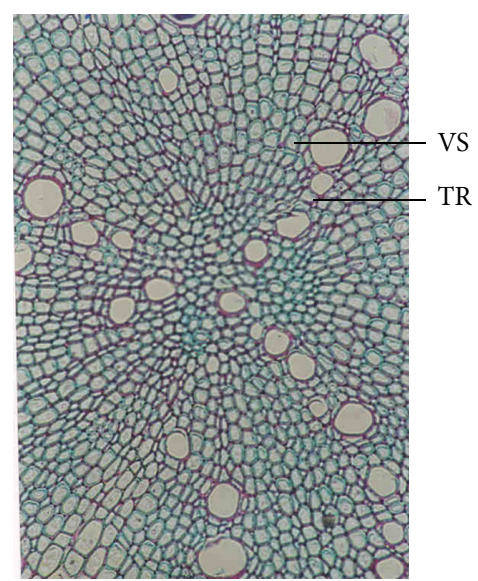

T.S. through central region

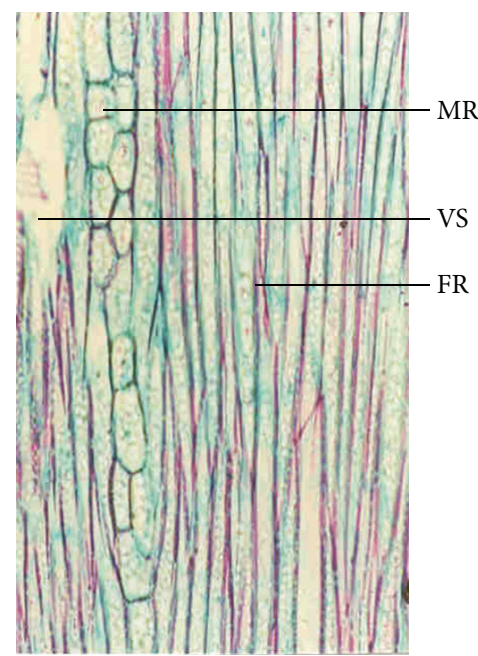

T.L.S. of root
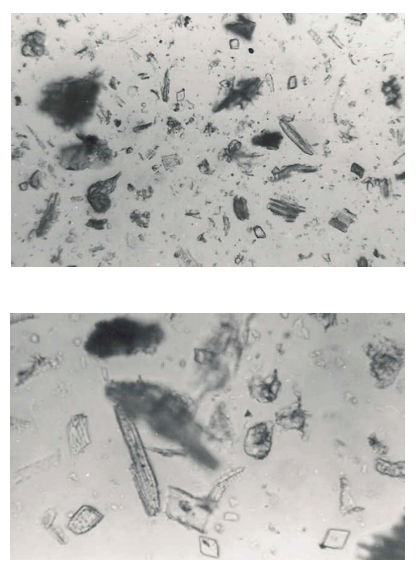

Powder study

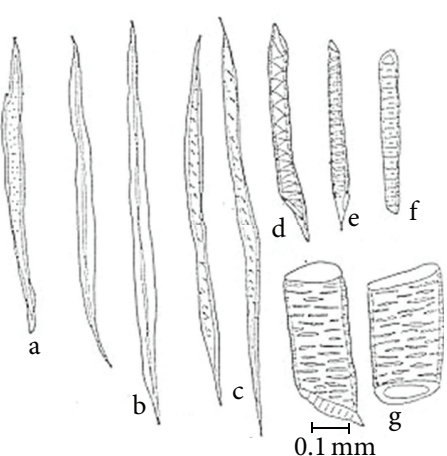

Maceration study

FIGURE 1: Anatomical characters of Berberis aristata root.

presented four species which reflects the use of molecular markers and sequence analysis for identification at inter- and intra-specific level [9-12].
Over exploitation of $B$. aristata created scarcity of the material that opened new vistas to identify a possible substitute for this species. During the market surveillance of 


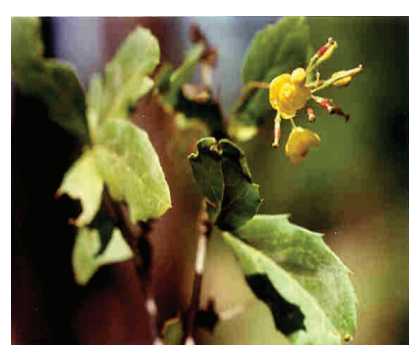

(a) A flowering twig

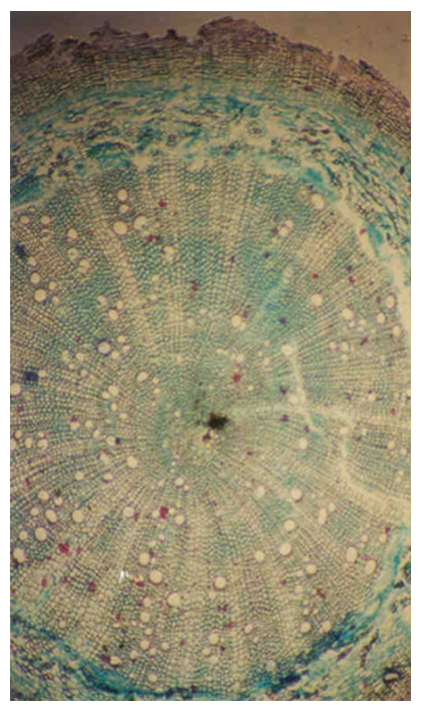

(c) T.S. outline of the root

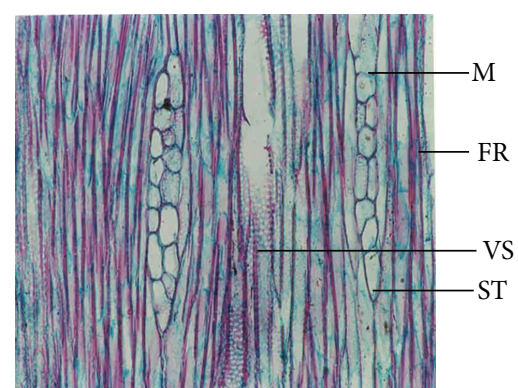

(e) TLS of the root

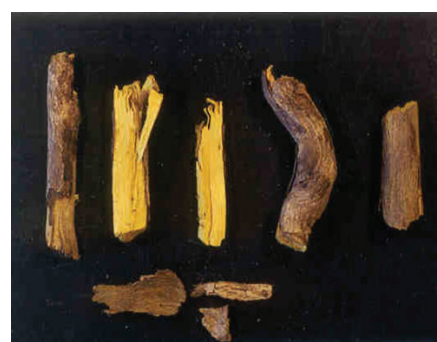

(b) Crude drug

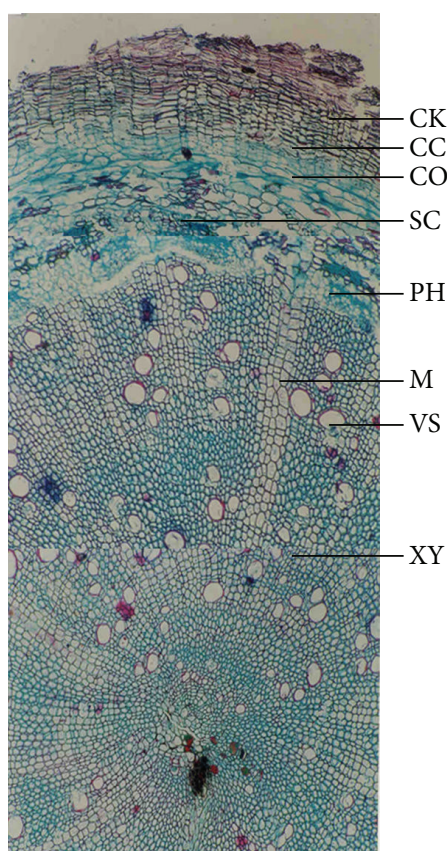

(d) TS cellular of the root

FIGURE 2: Anatomical characters of Berberis asiatica root.

different herbal drug markets of India, it was observed that almost all the markets either comprise Berberis lycium or Berberis asiatica. Although a detailed pharmacognostic study of $B$. aristata, B. asiatica, and B. chitria is reported by Srivastava et al. [13-15], market surveillance is not yet performed. Hence, the present study has been undertaken, which may be useful to pharmaceutical industries for the authentication of the commercial samples and to explore the possibilities of using other species as a substitute of $B$. aristata.

\section{Materials and Methods}

The plant materials were collected from the Dhanaulti (Uttaranchal) region of India (LWG 221238-11) and the roots were preserved in $70 \%$ ethyl alcohol for histological studies. Procurement of commercial samples was done from various important drug markets of India, namely, Aligarh, Amritsar, Bangalore-I, Bangalore-II, Delhi, Hyderabad, Jammu, Lucknow, Trichur, Varanasi, and so forth.

Microtome sections were cut and stained with safranin and fast green and photographed with Nikon F70X camera [16]. Physicochemical and phytochemical studies like total ash, acid insoluble ash, tannins, and total alkaloids were calculated from the shade dried powdered material according to the recommended procedures [17-19]. Further, heavy metal studies and quantitative estimation of berberine through HPTLC have also been performed as per ICH guidelines. 

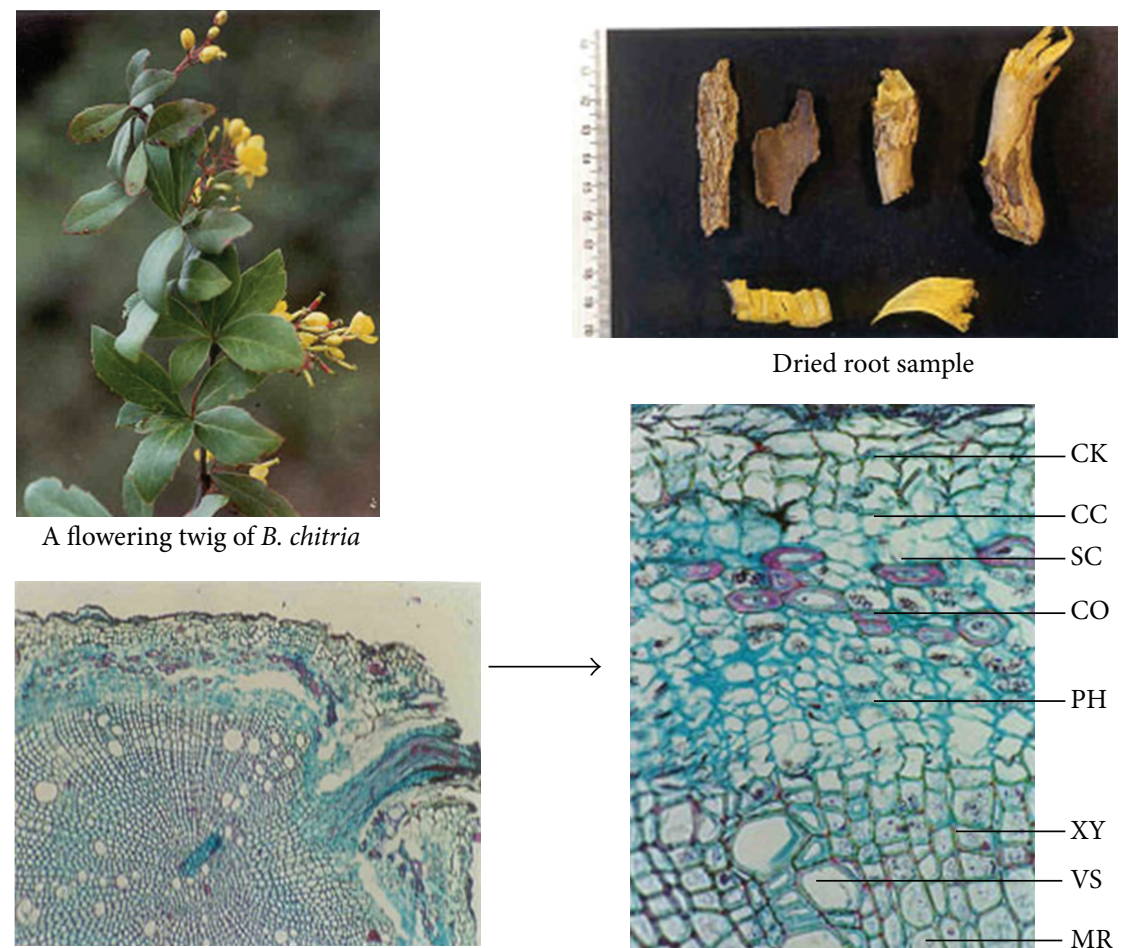

T.S. diagrammatic of root $(\times 100)$

$\downarrow$
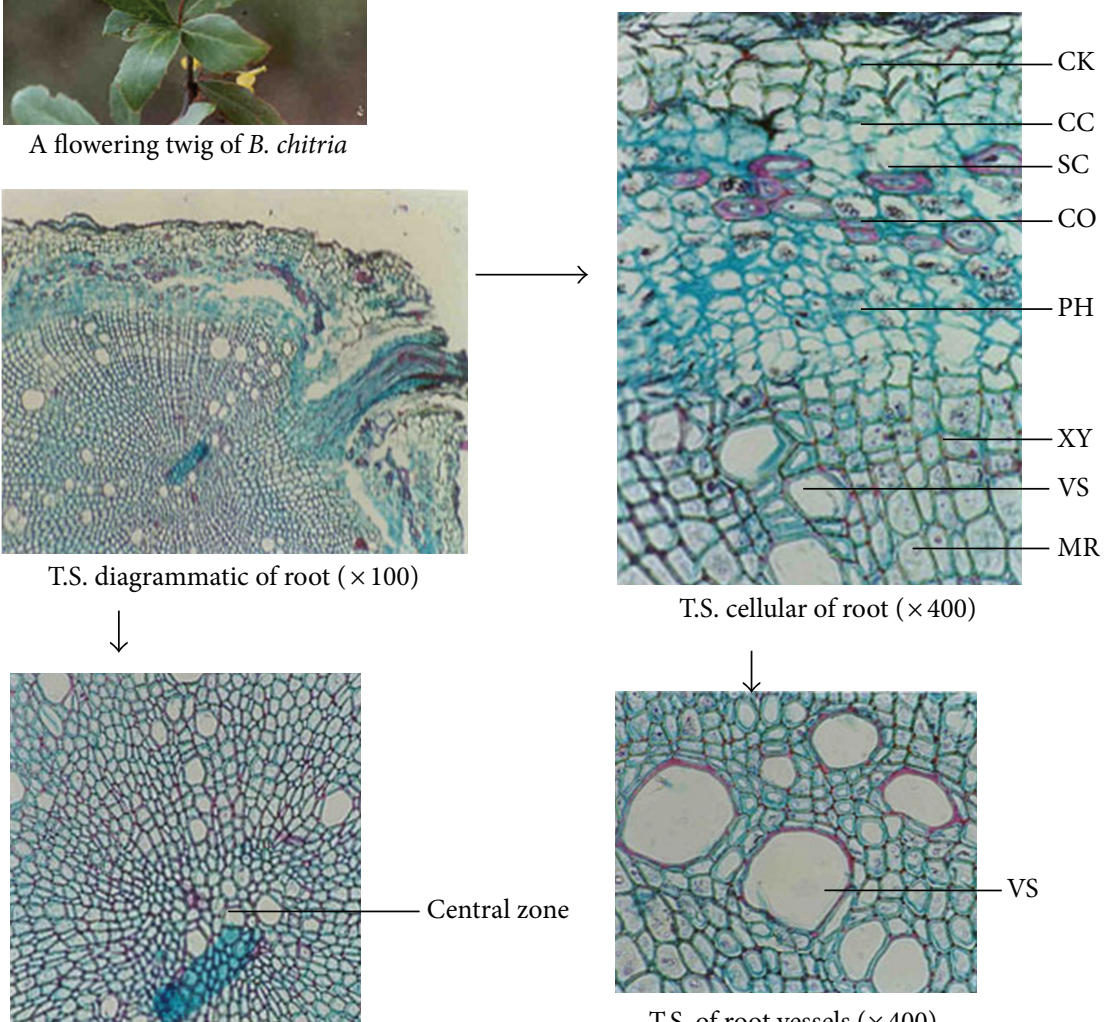

T.S. cellular of root $(\times 400)$

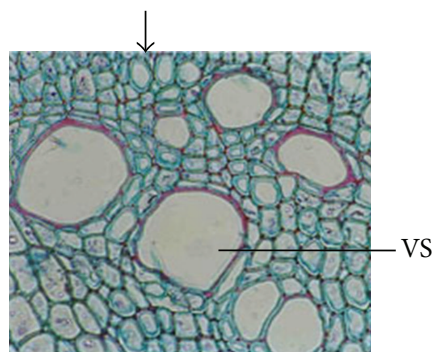

T.S. of root vessels $(\times 400)$

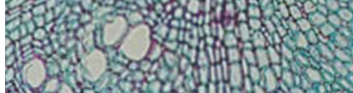

T.S. of root through central zone $(\times 100)$

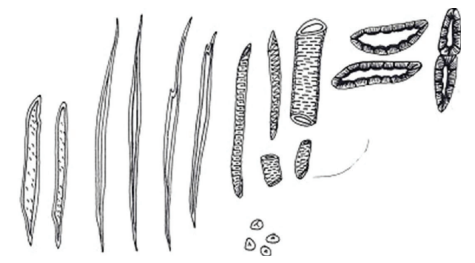

Macerated elements $(\times 400)$

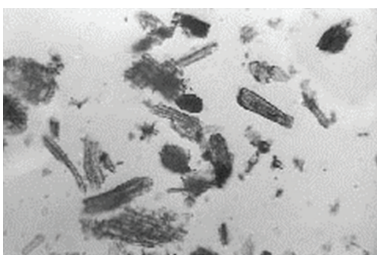

Powdered elements $(\times 400)$

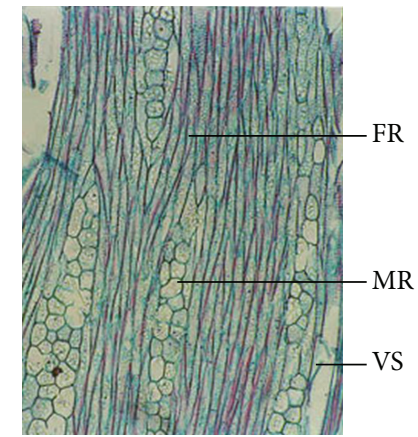

T.L.S. of $\operatorname{root}(\times 100)$

Figure 3: Anatomical characters of Berberis chitria root.

\section{Results and Discussion}

Morphological studies showed certain minor variations in all the four Berberis species (see Table 4). For example, in
$B$. aristata and B. chitria the cut surface is bright yellow while that of B. asiatica and B. lycium is lemon yellow, and deep yellow, respectively. Similarly the colour of wood bark has also minor variation, namely, it is yellowish brown to 


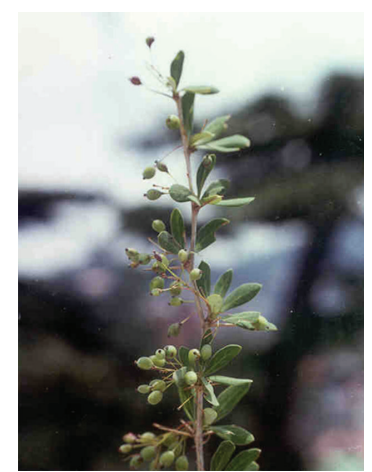

(a) A fruiting twig

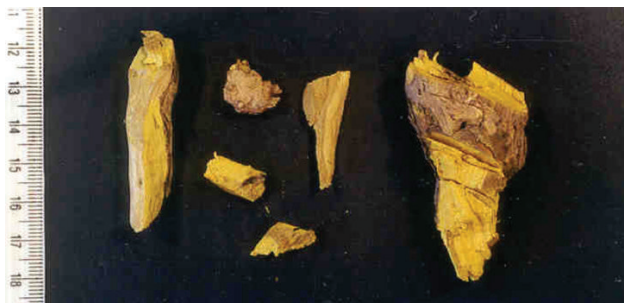

(b) Dried roots

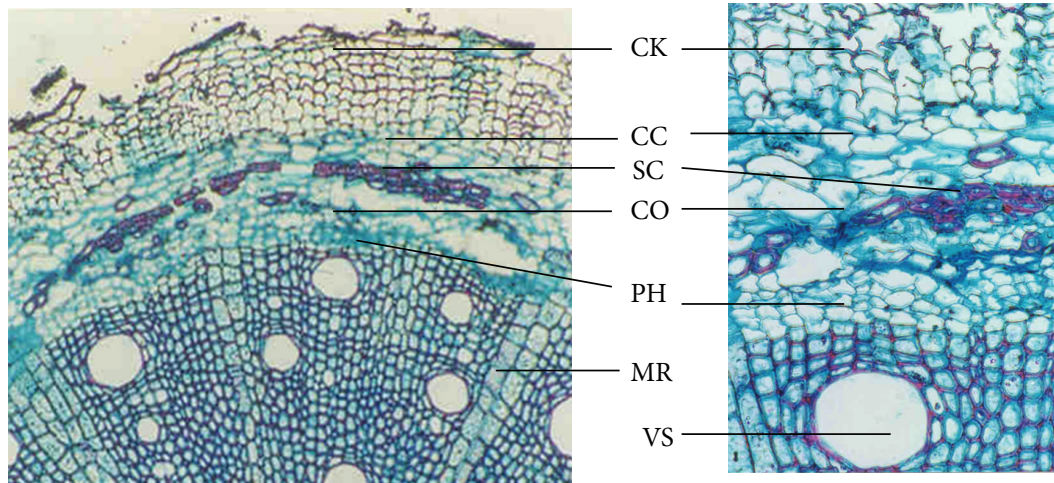

(d) T.S. cellualr of root $(\times 40)$

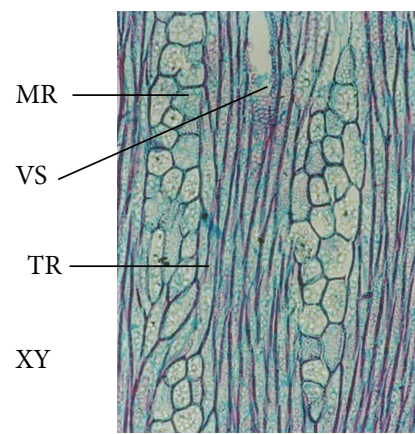

(f) L.S. root showing medullary rays $(\times 40)$

(c) T.S. cellular of root $(\times 25)$

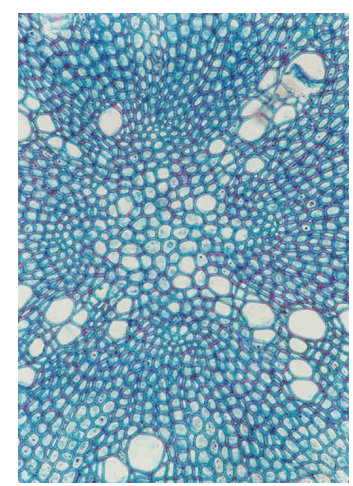

(e) T.S. root through central region $(\times 25)$

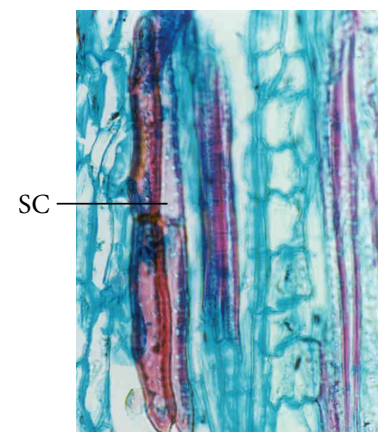

(g) L.S. root showing sclerieds $(\times 40)$

FIgURE 4: Anatomical characters of Berberis lycium root.

yellowish gray in all the three species except in B. lycium the colour is grayish white. Likewise the numbers of pericyclic fibres are different in all the four species, for example, the maximum is found in B. aristata and minimum in B. lycium (Tables 1, 2, and 3; Figures 1, 2, 3, and 4).

A comparative account of all physicochemical values has been depicted in histograms (Figures 5-10). It is quite clear from these studies that no significant variation was observed in total ash of all the four species of Berberis. However, the percentage of acid insoluble ash of roots and stem showed significant variations; for example, the highest percentage of $0.26 \%$ acid insoluble ash was observed in B. asiatica root and the lowest one of $0.05 \%$ was noted in B. aristata root (Figure 5). It is interesting to note that the percentage of alcohol and water-soluble extractives were higher in root as compared to stem except in B. chitria (Figure 6). On the contrary the percentage of starch was higher in stem (14-19\%) except in B. lycium (root) it was $26.03 \%$. Percentage of tannin was more or less similar in both in root and stem of all the samples $(0.7-1.7 \%)$.

Similarly, the percentage of successive Soxhlet extractive values revealed that alcohol, acetone, and water extractives were found to be significantly higher in B. aristata root, that is, $7.83 \%, 6.51 \%$ and $5.96 \%$ respectively. While the roots 


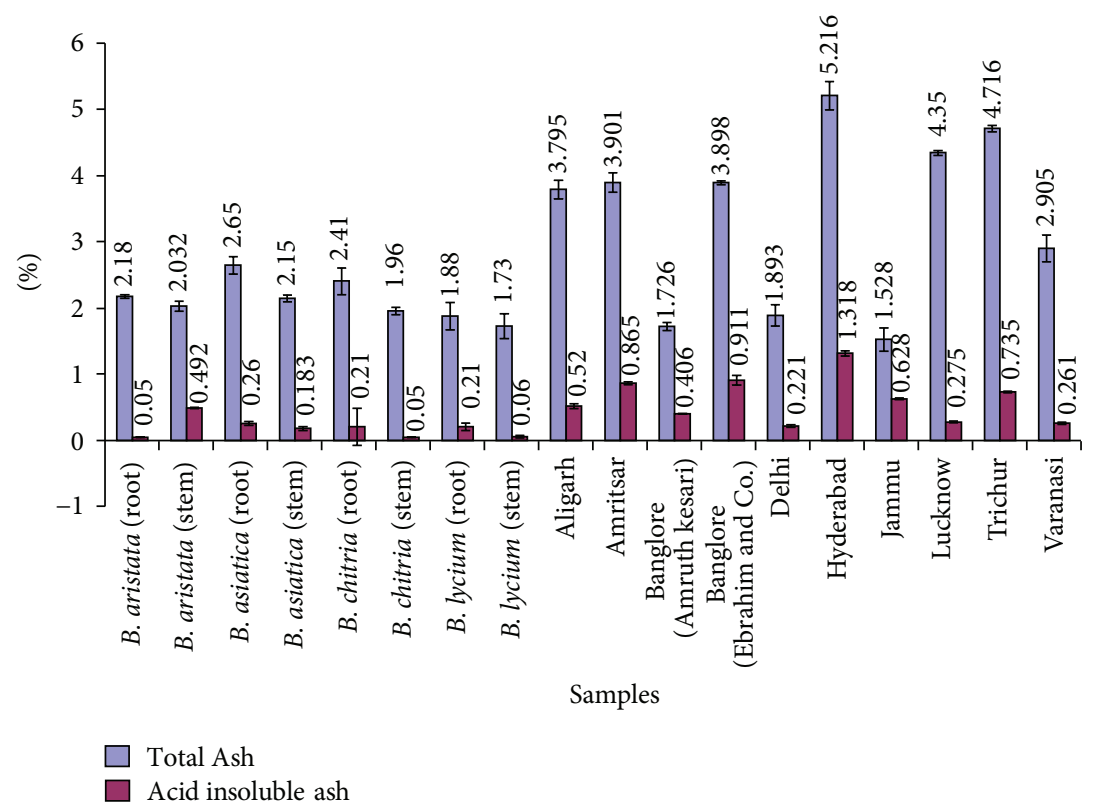

FIgURE 5: Comparative ash values of different Berberis species and market samples of Daruharidra.

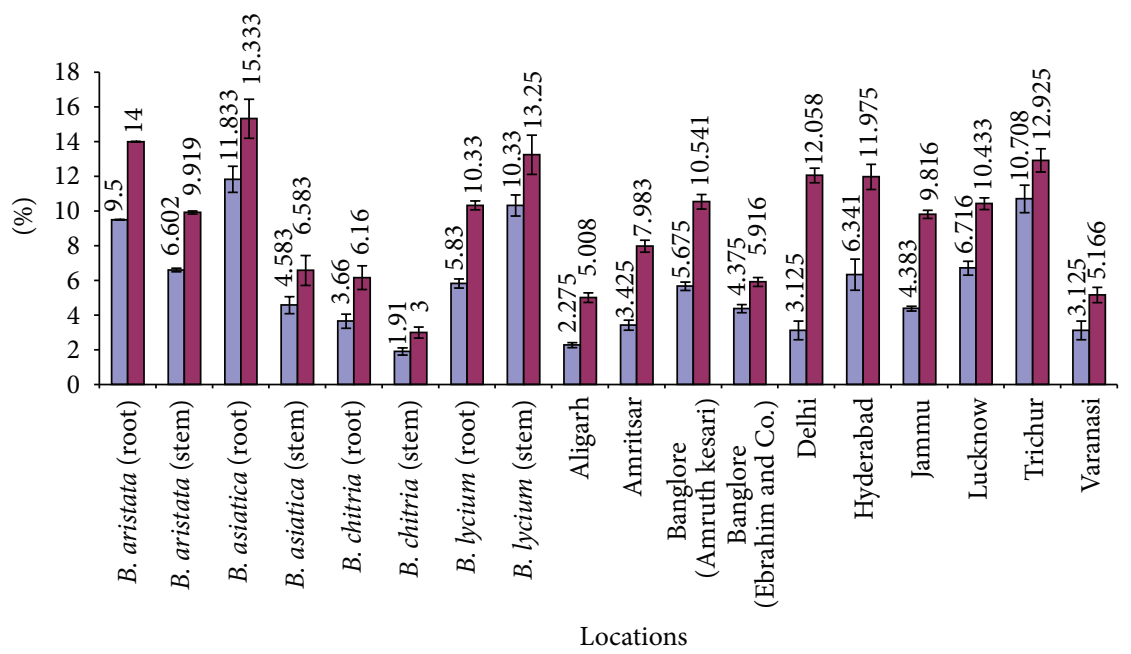

FIGURE 6: Comparative alcohol and water-soluble extractives values of different Berberis species and market samples of Daruharidra.

of $B$. asiatica possessed maximum percentage of alcoholic, acetone, and water-soluble matter, that is, $10.30 \%, 5.92 \%$, and $4.92 \%$, respectively. On the other hand the percentage of successive extractives in stem was maximum in B. lycium that is, $5.11 \%$ (acetone), $7.20 \%$ (alcohol), and $3.20 \%$ (water), respectively, and percentage of hexane soluble matter was higher in B. aristata (Figure 9).

The percentage of total crude alkaloid percentage was also estimated and it was found that it varied from species to species, that is, maximum in roots of B. chitria $(3.65 \%)$ followed by the roots of B. lycium (2.8\%), B. aristata $(2.45 \%)$, and $B$. asiatica $(2.4 \%)$, respectively. Besides, the active constituents berberine one of the major alkaloids was also calculated through HPTLC densitometric method (solvent system, n-propanol: water: formic acid, $90: 80: 0.4)$ and it was found more in roots as compared to stem, that is, $2.25-5.20 \%$ and $1.02-2.01 \%$, respectively. Its concentration was also varied from species to species, that is, maximum in roots of B. chitria (5.20\%) followed by B. lycium (3.99\%), B. aristata $(3.55 \%)$, and B. asiatica (2.25\%). Details are depicted in Figure 10.

A comparative study of official drug $B$. aristata sample with that of commercial samples was made (Figures 515) and it was found that the Bangalore-I sample has all the similar morphological characters of roots of $B$. asiatica, namely, (i) outer surface grayish brown with $2 \mathrm{~mm}$ thick friable bark, which was separated out immediately leaving muddy yellow surface of the wood; (ii) transversely cut surface lemon yellow; (iii) sclerieds mostly in groups of 2-12 rarely solitary and comparatively more than other three 


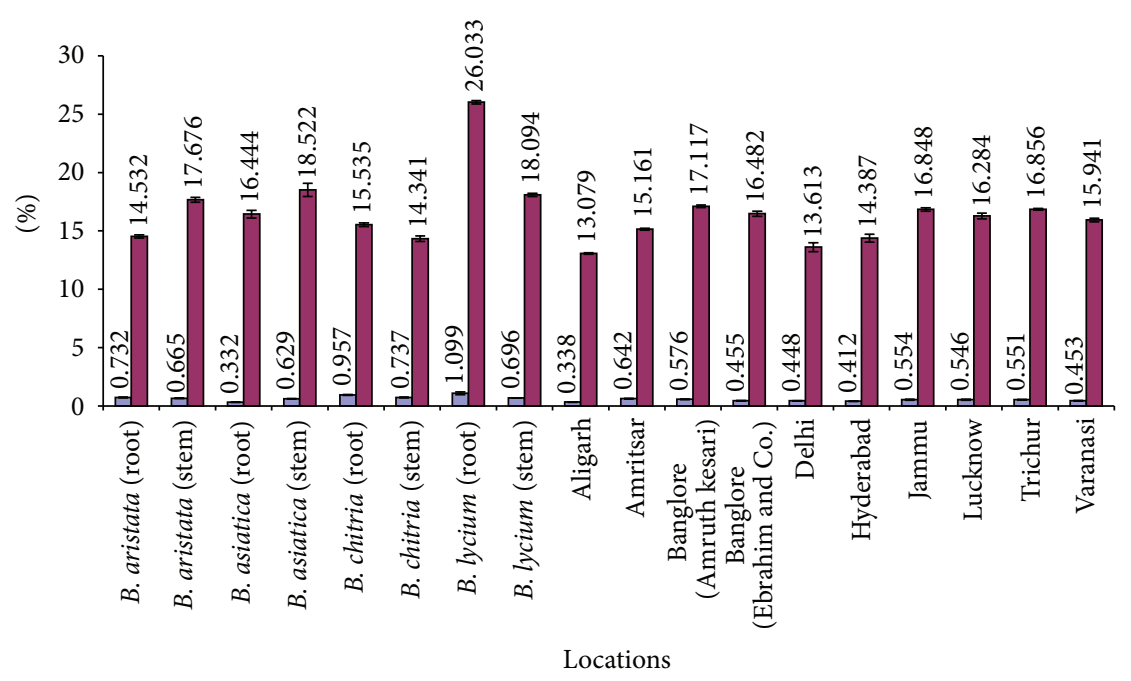

FIgURE 7: Comparative sugar and starch percentage of different Berberis species and market samples of Daruharidra.

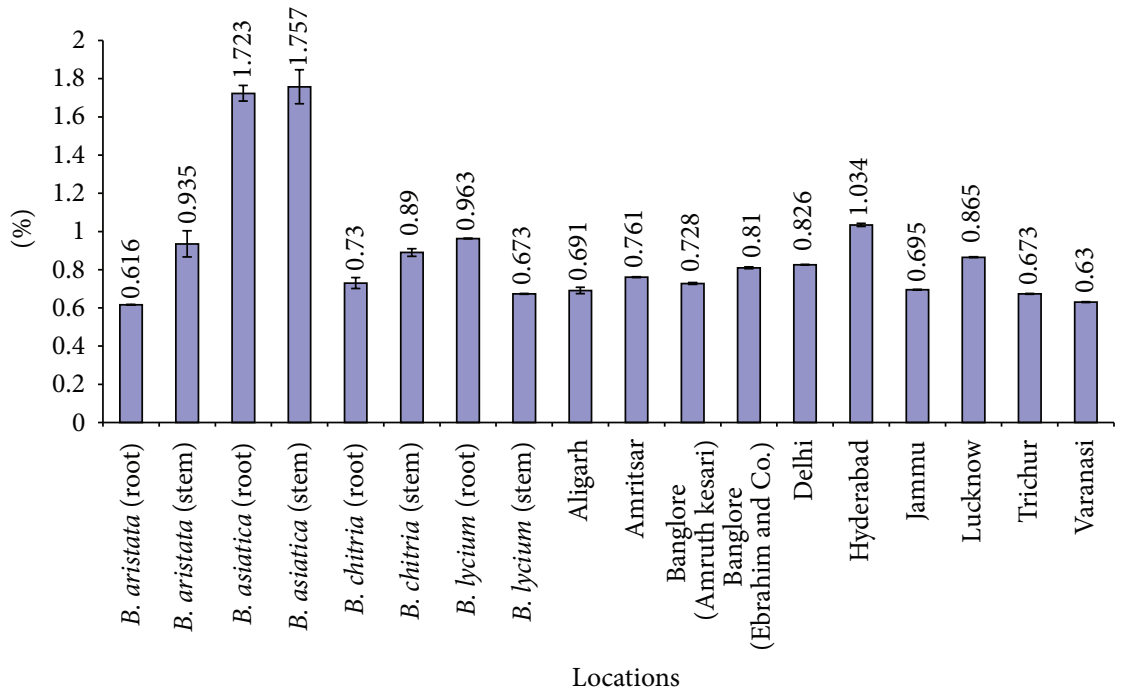

FIGURE 8: Comparative tannin percentage of different Berberis species and market samples of Daruharidra.

species; (iv) pericycle fibres interrupted by stone cells; (v) length of the vessel elements much more than the other species, that is, up to $500 \mu \mathrm{m}( \pm 181.0)$; (vi) physicochemical values are within the prescribed range (Table 6) of Ayurvedic Pharmacopoeia of India [9], hence, identified as roots of $B$. asiatica.

Similarly majority of anatomical characters of Aligarh and Varanasi samples matched with the stem and roots of $B$. asiatica in having (i) some pieces with fine longitudinal ridges and small warts on the outer surface of bark and dark brown outer surface of wood; (ii) transversely cut surface lemon yellow; (iii) sclerieds rarely solitary mostly in groups of 2-12 and comparatively more than other three species; (iv) pericycle fibres interrupted by stone cells; (v) length of the vessel elements much more than the other species up to $600 \mu \mathrm{m}( \pm 181.0)$; (vi) trachieds up to $680 \mu$ $( \pm 167.0)$ long; (vii) some other pieces have grayish brown outer surface with $2 \mathrm{~mm}$ thick friable bark which was separated out immediately leaving muddy yellow surface of the wood; presence of prominent pith as in stem of $B$. asiatica.

Furthermore, the commercial samples of Delhi and Lucknow showed close resemblance with the stem of $B$. asiatica by the presence of (i) fine longitudinal ridges and small warts on the outer surface of bark and yellowish creamy transverse cut surface; (ii) dark brown outer surface of wood as appeared after peeling off the bark; (iii) sclerieds rarely solitary mostly in groups of 2-12 and comparatively more than other three species; (iv) pericycle fibres interrupted by stone cells; (v) trachieds up to $680 \mu( \pm 167.0)$ and vessels up to $600 \mu( \pm 102.0)$ long (vi) pith.

Similarly, the market samples of Amritsar and Jammu were found to be the mixture of stem and root of two different Berberis species. Amritsar samples were found to be the stem 


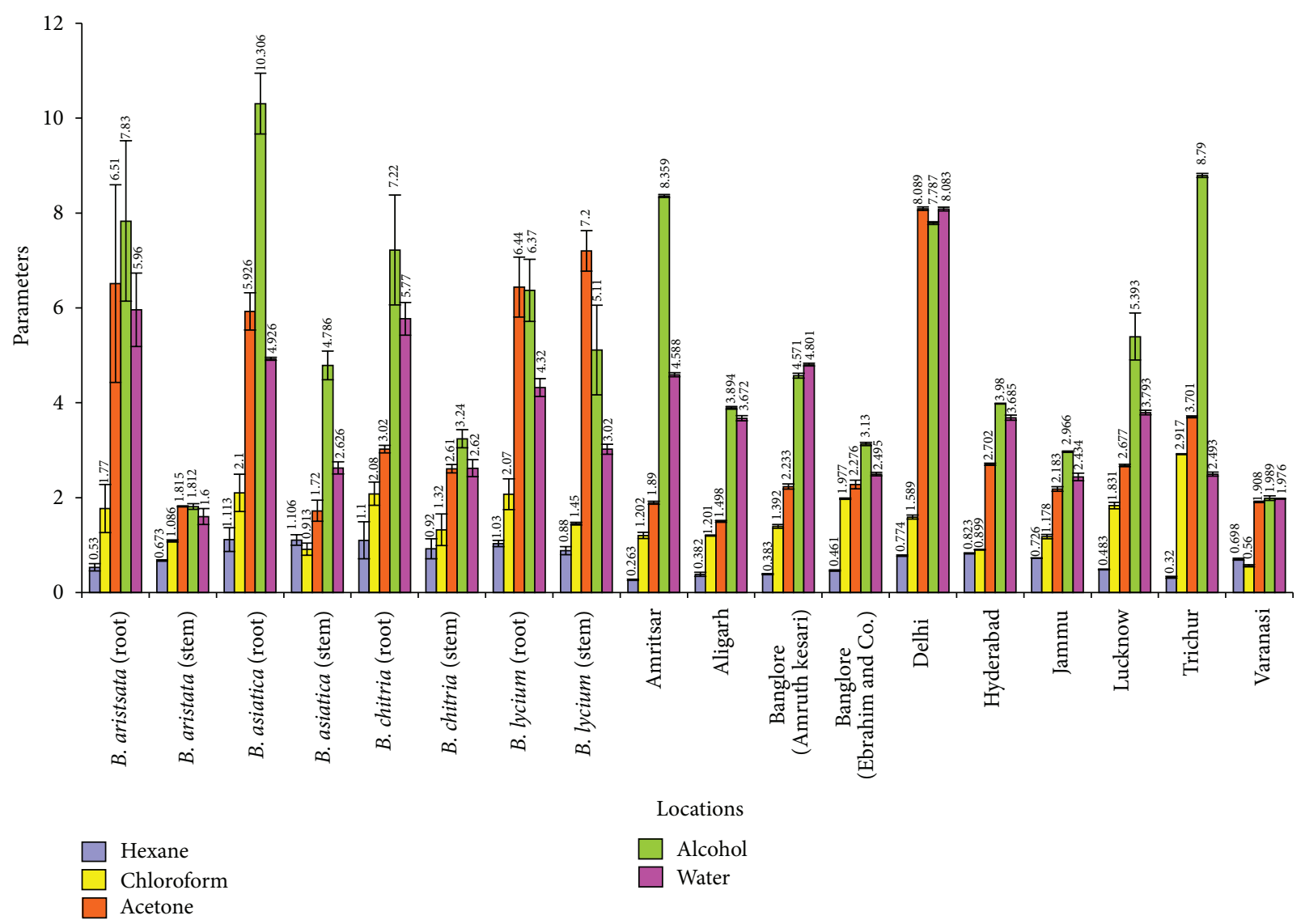

FIGURE 9: Comparative successive soxhlet extractive values of different Berberis species and market samples of Daruharidra.

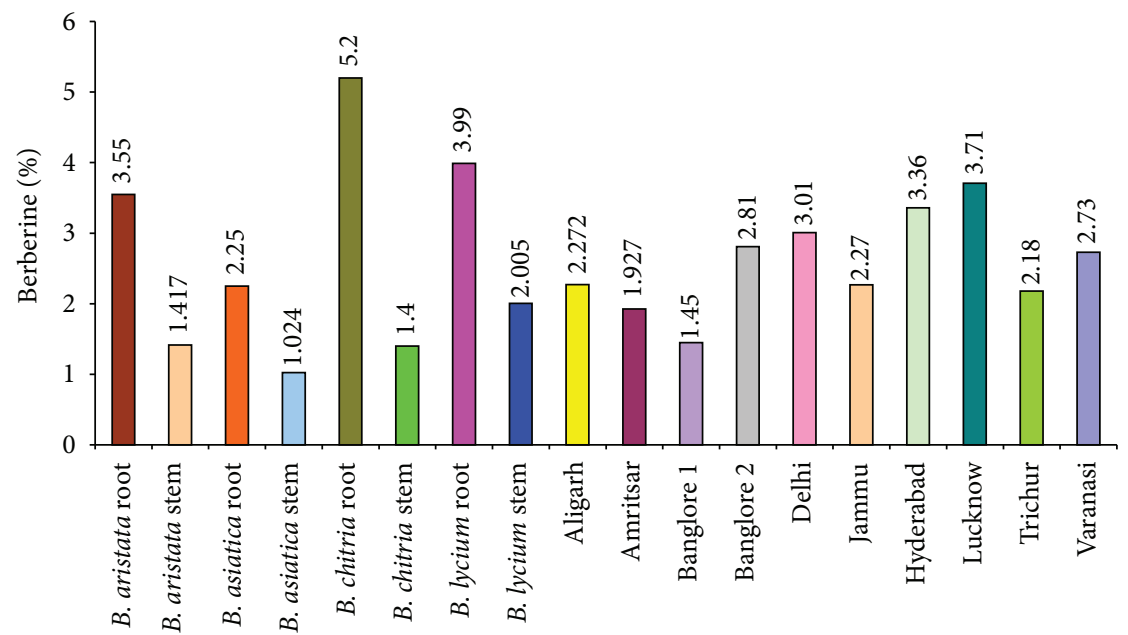

FIGURE 10: Quantitative estimation of berberine in different species of Berberis and market samples of Daruharidra.

of $B$. aristata and root of $B$. asiatica while Jammu sample comprised of root of $B$. chitra and stem of B. asiatica.

The morphological characters in Amritsar sample are (i) outer surface creamish brown with knots, fine longitudinal ridges, and flakes; (ii) bark very thin and brittle; (iii) transverse cut surface bright yellow; (iv) outer surface of wood which appeared after peeling off the bark was yellowish brown; (v) sclerieds solitary or in a group of 2-10; (vi) pericyclic fiber mostly solitary, rarely in groups of 2-10; (vii) length of the fibres much more, that is, about $630 \mu \mathrm{m}$ as compared to other three species.

On the other hand some of the pieces of this sample showed close resemblance with that of the stem of B. asiatica in having (i) outer surface grayish brown with $2 \mathrm{~mm}$ thick 


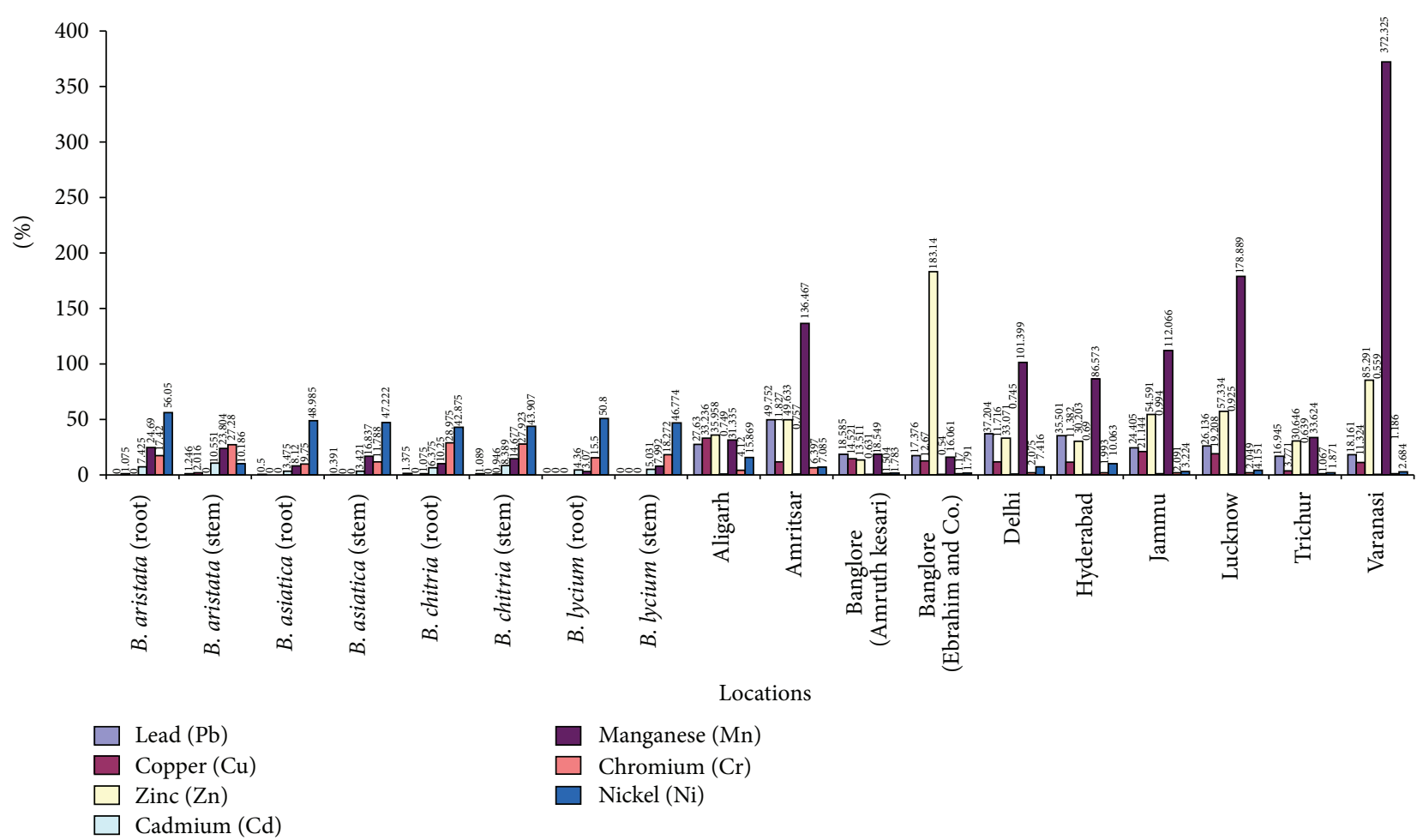

FIGURE 11: Comparative heavy metal studies of different Berberis species and market samples of Daruharidra.

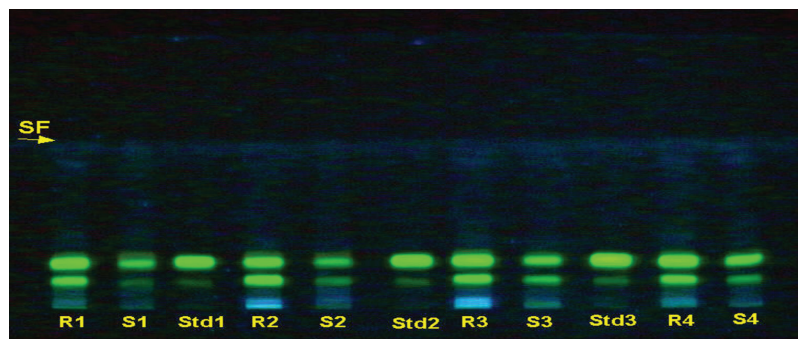

FIGURE 12: 8 HPTLC profile of different Berberis species (under UV 366) (solvent system: n-propanol: water: formic acid, $90: 80: 0.4)$.

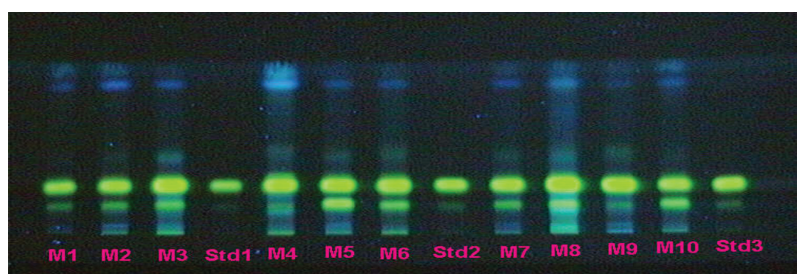

FIGURE 13: HPTLC profile of different market samples of Daruharidra (under UV 366); (Solvent system: n-propanol: water: formic acid, $90: 80: 0.4)$.

friable bark which was separated out immediately leaving muddy yellow surface of the wood; (ii) transverse cut surface lemon yellow (iii) sclerieds rarely solitary mostly in groups of 2-12 and comparatively more than other three species (iv) pericycle fibres interrupted by stone cells; (v) length of the
TABLE 5: Market samples of different regions from India.

\begin{tabular}{|c|c|c|}
\hline $\begin{array}{l}\text { Serial } \\
\text { number }\end{array}$ & Markets & Findings \\
\hline 1 & Amritsar & $\begin{array}{l}\text { Mixture of root of B. asiatica and } \\
\text { stem of } B \text {. aristata }\end{array}$ \\
\hline 2 & Aligarh & Mixture of root and stem of B. asiatica \\
\hline 3 & Banglore I & Root of $B$. asiatica \\
\hline 4 & Banglore II & Stem of Coscinium fenestratum \\
\hline 5 & Delhi & Stem $B$. asiatica \\
\hline 6 & Hyderabad & $\begin{array}{l}\text { Mixture of } \operatorname{root} B \text {. asiatica } \\
\text { Root } B \text {. aristata } \\
\text { Root of } B \text {. tinctoria }\end{array}$ \\
\hline 7 & Jammu & $\begin{array}{l}\text { Mixture of root of } B \text {. chitria and stem of } \\
\text { B. asiatica }\end{array}$ \\
\hline 8 & Lucknow & Stem of $B$. asiatica \\
\hline 9 & Trichur & Root of Coscinium fenestratum \\
\hline 10 & Varanasi & Mixture of root and stem of $B$. asiatica \\
\hline
\end{tabular}

vessel elements much more than the other species, that is, up to $500 \mu \mathrm{m}( \pm 102.0)$; (vi) presence of pith.

Similarly the morphological characters found in some pieces of Jammu samples showed close resemblance with those of stem of B. asiatica, as in Delhi and Lucknow markets. However, some other characters similar to roots of $B$. chitria. The different characters, this market samples showed are (i) outer surface light brown in colour with broad ridges and grooves and transverse marks; (ii) 

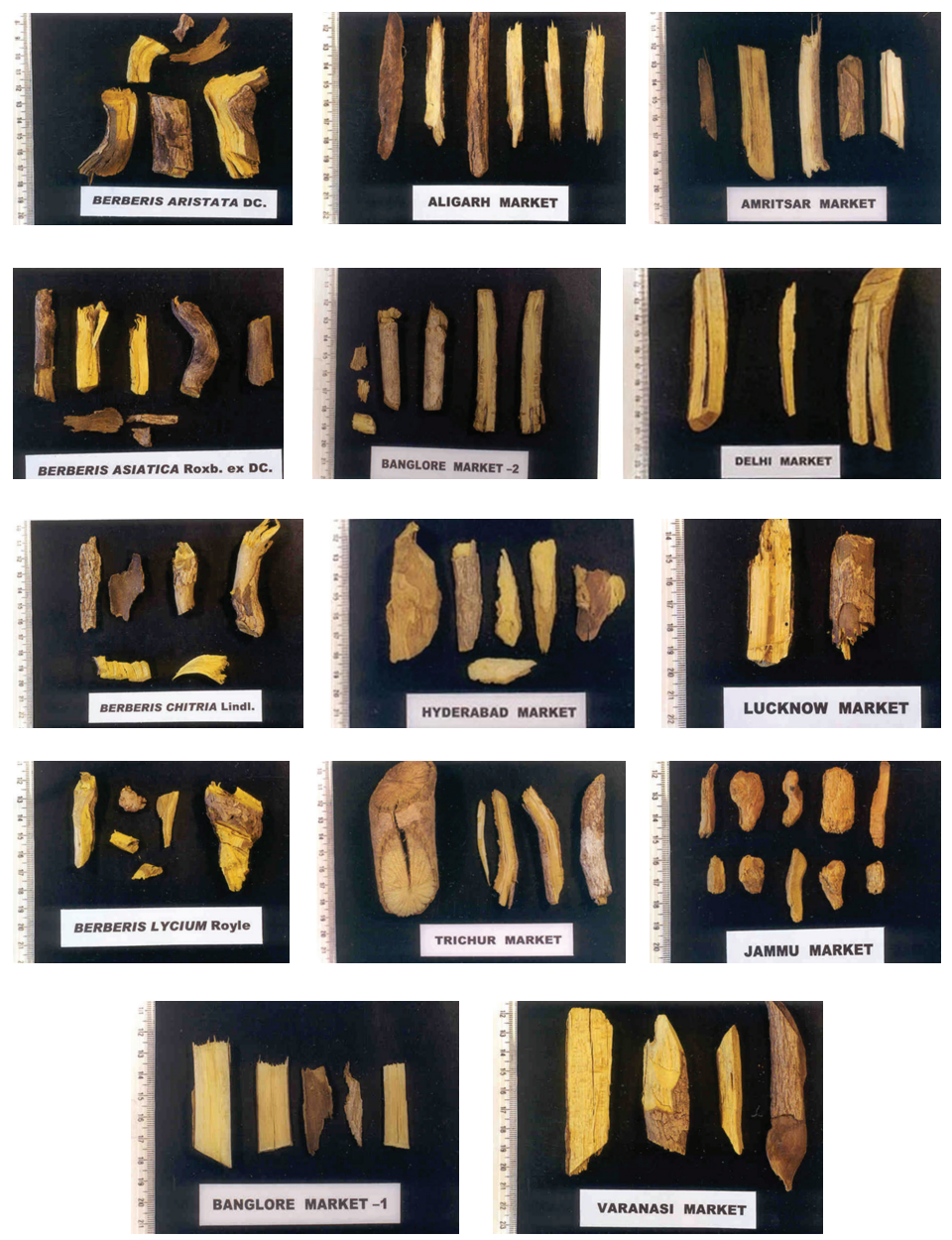

FIGURE 14: Crude samples of Daruharidra fromdifferent market of India.

TABLE 6: Identity, purity, and strength as prescribed by Ayurvedic Pharmacopoeia of India.

\begin{tabular}{ll}
\hline Parameters & Values \\
\hline Foreign matter & Not more than 2 percent \\
Total ash & Not more than 14 percent \\
Acid-insoluble ash & Not more than 5 percent \\
Alcohol-soluble extractive & Not less than 6 percent \\
Water-soluble extractive & Not less than 8 percent \\
\hline
\end{tabular}

bark up to $5 \mathrm{~mm}$ thick but not easily detachable as in other three species; (iii) transverse cut surface bright yellow (iv) sclerieds mostly in groups of 2-4; (v) pericycle fibres present but are much lesser in number than $B$. aristata and B. asiatica; tracheidal fibres up to $960 \mu \mathrm{m}( \pm 86.0)$ long.

The percentage of successive extractives (Soxhlet), sugar, starch, and berberine content also support the above finding (Figures 6-10).

On the contrary the Hyderabad commercial sample seems to be the mixture of three Berberis species. Some pieces showed close affinity with roots of $B$. asiatica; other pieces resembled roots of $B$. aristata. Besides some of the pieces have no resemblance with any of the four species studied. These may be the roots of $B$. tinctoria as it is a common species found in these areas.

The samples procured from Trichur and Bangalore II do not resemble any of the Berberis species studied. Presence of wedge shaped medullary rays and wheel shaped transverse section indicate that these pieces may belong to Menispermaceae. Hence an attempt was made to compare the characters of these samples with the root and stem of Coscinium fenestratum. After comparison it was found that samples procured from Trichur and Bangalore II were root and stem of $C$. fenestratum Gaertn, respectively.

From the heavy metal analysis of crude drug samples of different herbal market, it was observed that the concentration of majority of heavy metals, namely, Cd, Co, Mn, $\mathrm{Zn}$, and $\mathrm{Cu}$ within the permissible limits of WHO in both the collected and commercial samples. However, the significant variations in Lead concentration were observed in both samples that is, in collected as well as in commercial ones. For example, in the stem of collected samples, the increase is quite low but in some of the commercial samples, namely, Amritsar, Delhi, and Hyderabad many fold increase in lead concentration was observed, this may be due to vehicular pollution or may be due to edaphic factors (Figure 11). 

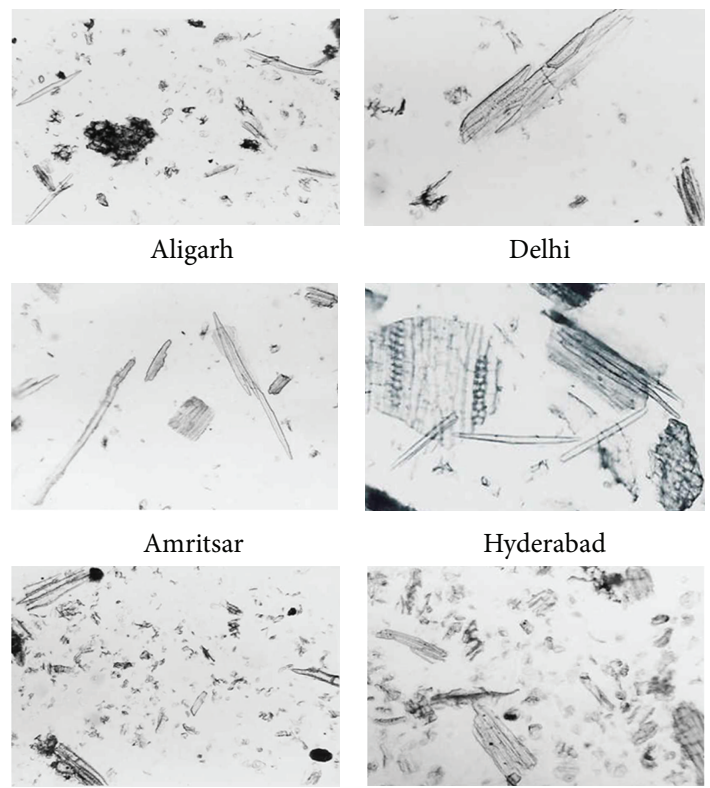

Bangalore
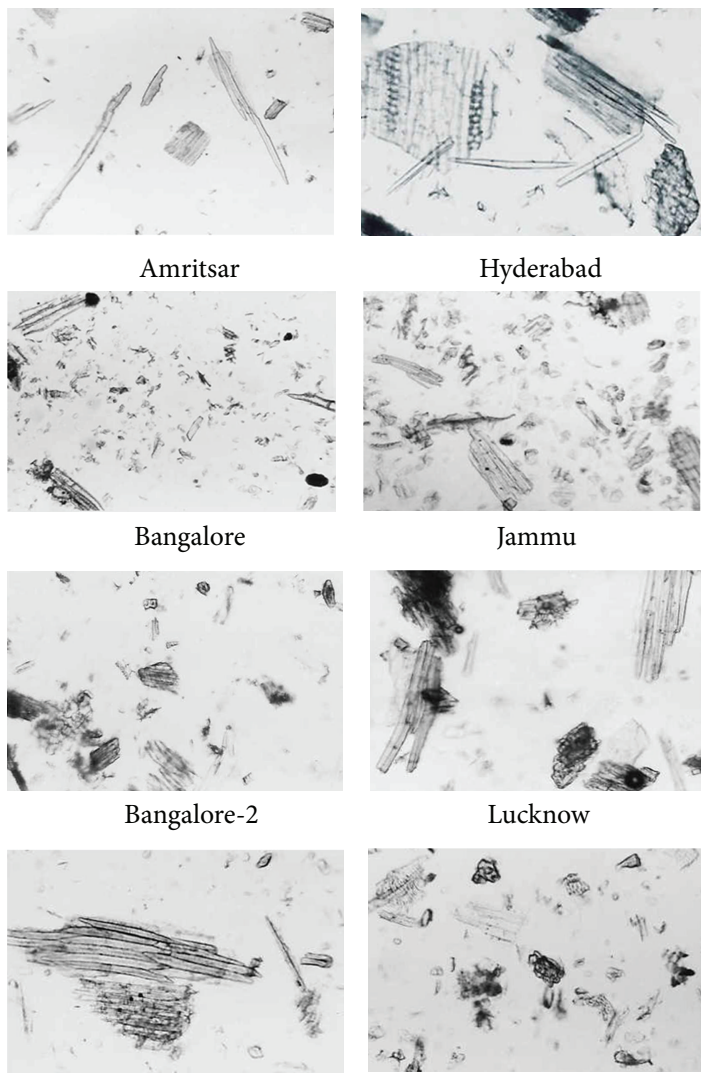

Trichur

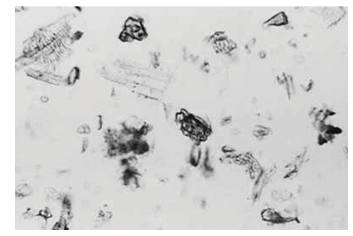

Varanasi

FIgURE 15: Powder study of different market samples of Daruharidra.

\section{Conclusion}

From the ongoing discussion it is quite clear that most of the commercial samples consist of mixture of roots or stems of Berberis asiatica while $B$. aristata is found only in the market samples of Amritsar and Hyderabad mixed with roots of $B$. asiatica.

On the basis of the above study it may be concluded that in India different Berberis species and their parts are being sold in the name of crude drug Daruharidra (Table 5).

\section{References}

[1] G. Watt, "Economic Products of India V, The Superintendent of Government Printing," India, 652-653, 1883.

[2] K. R. Kirtikar and B. D. Basu, Indian Medicinal Plants I, Lalit Mohan Basu, Allahabad, India, 1933.

[3] R. N. Chopra, T. C. Chopra, K. L. Handa, and L. D. Kapoor, Chopra's Indigenous Drugs of India, vol. 284, UN Dhar and Sons Pvt, 1958.
[4] "The wealth of India Berberis Linn. (Berberidaceae). Ed Ambastha Sp Publication and Information Directorate," CSIR, New Delhi, India, 2B, pp. 114-118, 1988.

[5] S. Samhita, Chaukhamba Sanskrit Sansthan, Sutrasthanam Lakshadi Group, Varanasi, India, 1963, Edited by: K. K. Bhishagratna.

[6] N. K. Dutta and M. V. Panse, "Usefulness of berberine (an alkaloid from Berberis aristata) in the treatment of cholera," Indian Journal of Medical Research, no. 50, pp. 732-735, 1962.

[7] S. C. Lahiri and N. K. Dutta, "Berberine and chloramphenicol in the treatment of cholera and severe diarrhoea," Journal of the Indian Medical Association, vol. 48, no. 1, pp. 1-11, 1967.

[8] Department of Health, Ministry of Health and Family Welfare, The Ayurvedic Pharmacopoeia of India, Part I, Government of India, New Delhi, India, 2004.

[9] A. Kumar, P. Pushpangadan, and S. Mehrotra, "Extraction of high-molecular-weight DNA from dry root tissue of Berberis lycium suitable for RAPD," Plant Molecular Biology Reporter, vol. 21, article 309, 2003.

[10] V. Tripathi, S. Goswami, and P. Pushpangadan, "Isolation and expression analysis of Berberis chitria Lidl. specific transcripts 
using subtractive hybridization technique," African Journal of Plant Science, vol. 4, no. 12, pp. 488-495, 2010.

[11] M. C. J. Bottini, E. J. Greizerstein, M. B. Aulicino, and L. Poggio, "Relationships among genome size, environmental conditions and geographical distribution in natural populations of NW patagonian species of Berberis L. (Berberidaceae)," Annals of Botany, vol. 86, no. 3, pp. 565-573, 2000.

[12] S. Roy, A. Tyagi, V. Shukla et al., "Universal plant DNA barcode loci may not work in complex groups: a case study with Indian berberis species," PLoS One, vol. 5, no. 10, Article ID e13674, 2010.

[13] S. K. Srivastava, S. Khatoon, A. K. S. Rawat, S. Mehrotra, and P. Pushpangadan, "Pharmacognostic evaluation of the root of Berberis aristata DC", Natural Product Sciences, vol. 7, no. 4, pp. 102-106, 2001.

[14] S. K. Srivastava, A. K. S. Rawat, and S. Mehrotra, "Pharmacognostic evaluation of the root of Berberis asiatica," Pharmaceutical Biology, vol. 42, no. 6, pp. 467-473, 2004.

[15] S. K. Srivastava, A. K. S. Rawat, M. Srivastava, and S. Mehrotra, "Pharmacognostic evaluation of the roots of Berberis chitria Lindl," Natural Product Sciences, vol. 12, no. 1, pp. 19-23, 2006.

[16] K. Peach and M. V. Tracy, Modern Methods of Plant Analysis, vol. 3-4, Springer, Heidelberg, Germany, 1955.

[17] Indian Pharmacopoeia, Government of India, New Delhi, India, 2nd edition, 1965.

[18] J. Siwon, R. Verpoorte, G. F. A. Van Essen, and A. B. Svendsen, "Studies on Indonesian medicinal plants. III: the alkaloids of Coscinium fenestratum," Planta Medica, vol. 38, no. 1, pp. 24-32, 1980.

[19] Official Methods of Analysis (AOAC), Association of Official Chemists, New York, NY, USA, 4th edition, 1984. 


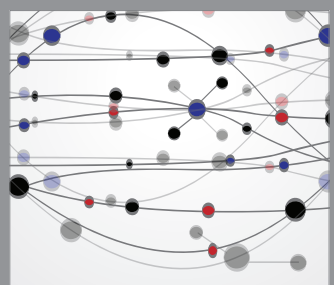

The Scientific World Journal
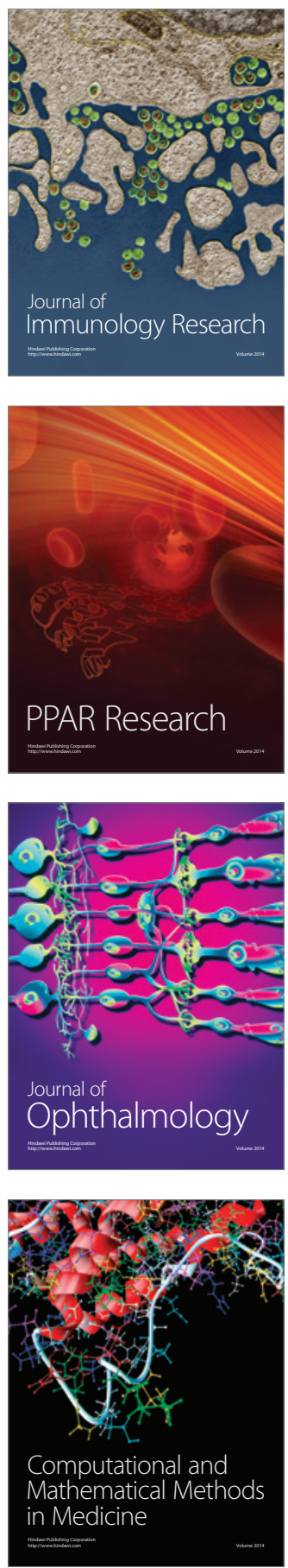

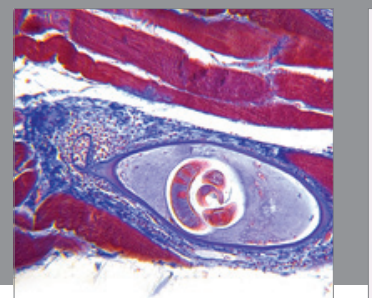

Gastroenterology

Research and Practice
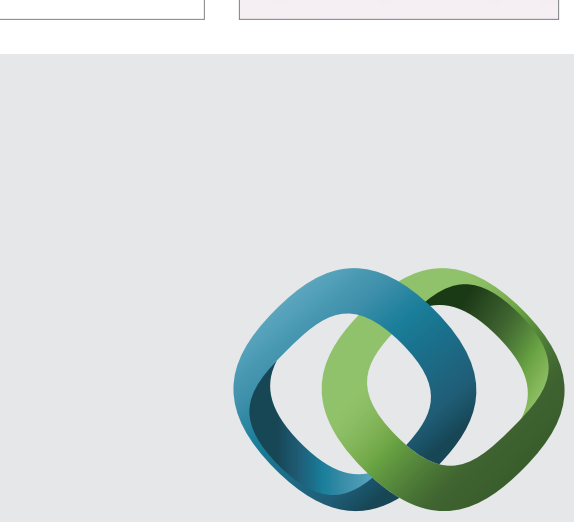

\section{Hindawi}

Submit your manuscripts at

http://www.hindawi.com
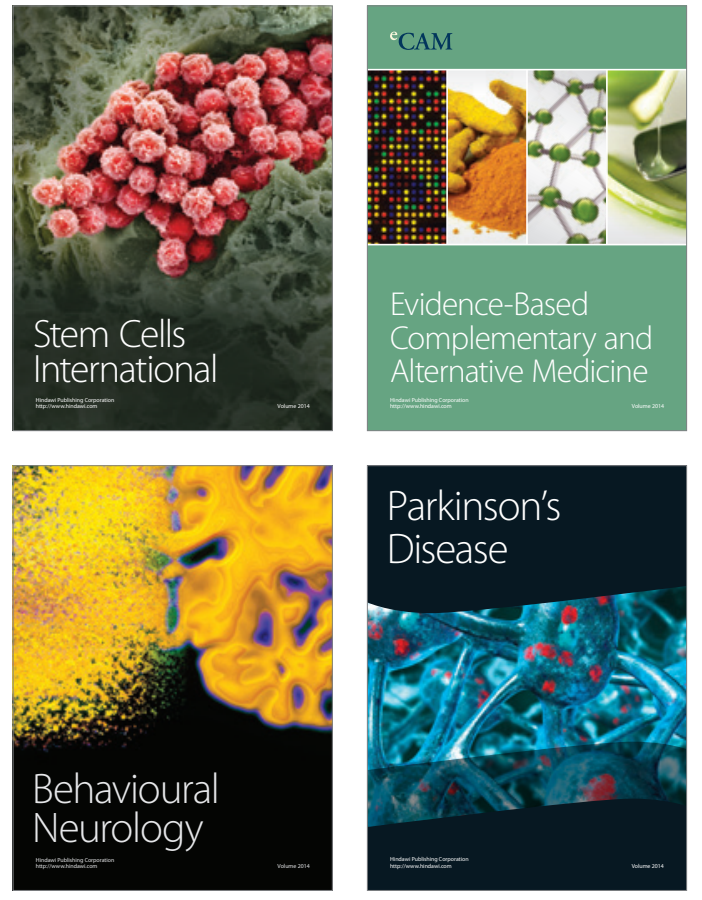
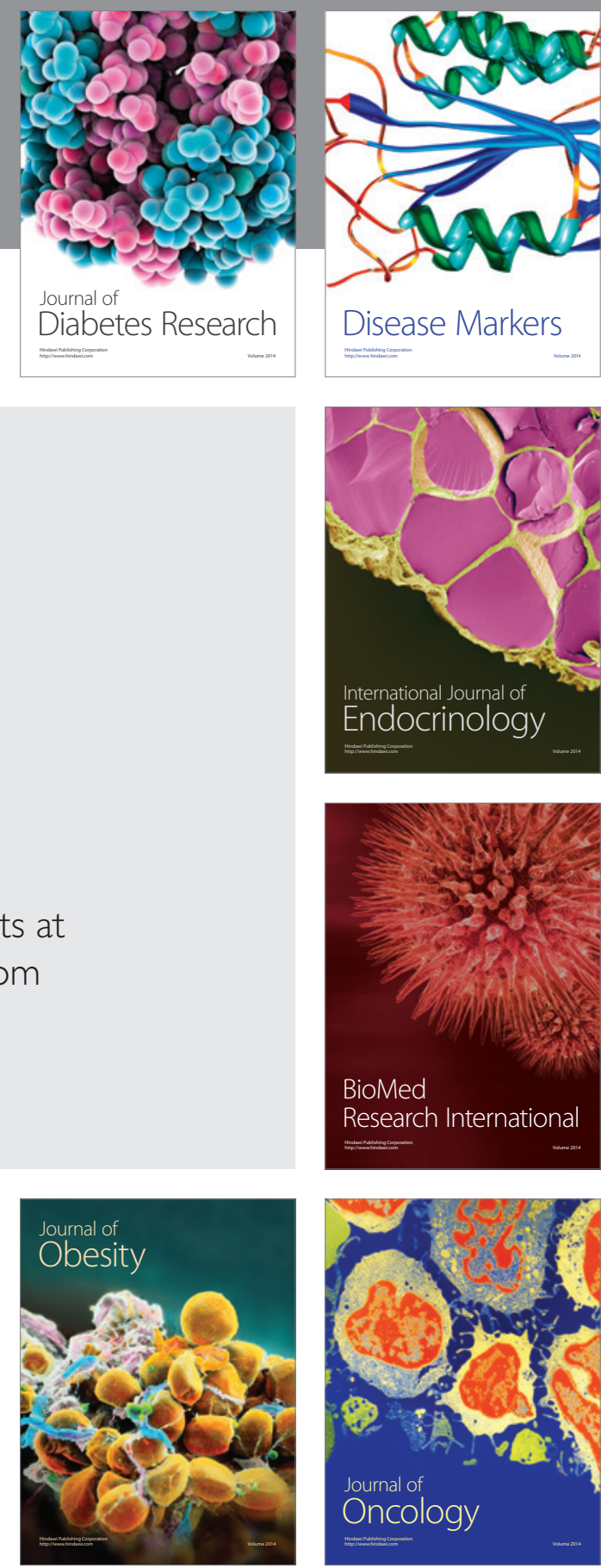

Disease Markers
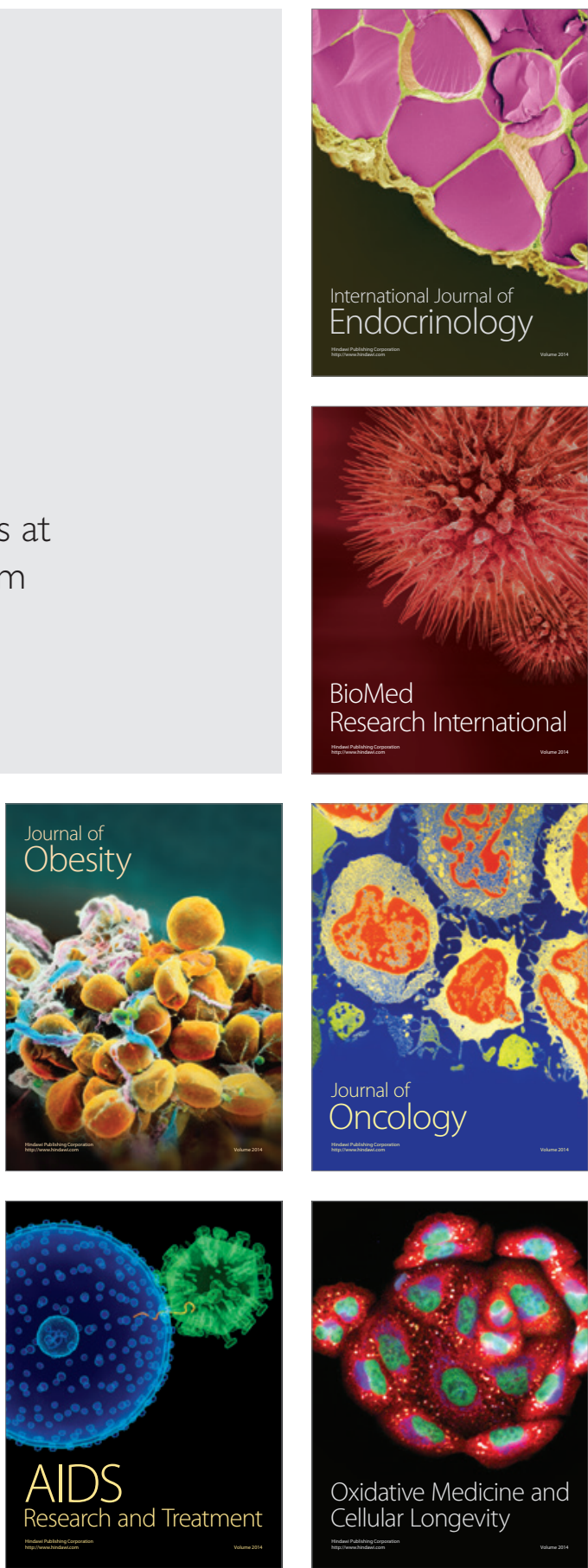